\title{
Filozofie na gymnáziu
}

\section{Philosophy in High School}

\section{Tomáš Měštánek}

Jsem učitelem předmětu, který se většinou jmenuje základy společenských věd (ZSV), podle Rámcového vzdělávacího programu (RVP) občanský a společenskovědní základ (OSZ) anebo nějak jinak, protože školy mohly zvolit pojmenování vlastní. A je začátek školního roku, v němž se v uvedeném předmětu učí filozofie. Co mám před sebou? Zhruba padesát vyučovacích hodin, dva a půl až tři tisíce let vývoje myšlení, kolem třicítky studentů zpravidla posledního ročníku gymnázia a 42. stranu zavazujícího RVP. V sobě pak chovám nějaký záměr, cíl, očekávání. Ano, očekávání, to je to správné slovo. I tvůrci RVP ho mají a nám nezbývá než ho citovat. (Nebojte se, nebude to dlouhé.)

\section{Úvod do filozofie a religionistiky}

\section{Očekávané výstupy}

\section{žák}

- objasní podstatu filozofického tázání, porovná východiska filozofie, mýtu, náboženství, vědy a umění k uchopení skutečnosti člověka

- rozliší hlavní filozofické směry, uvede jejich klíčové představitele a porovná řešení základních filozofických otázek v jednotlivých etapách vývoje filozofického myšlení

- eticky a věcně správně argumentuje v dialogu a diskusi, uvážlivě a kriticky přistupuje $\mathrm{k}$ argumentům druhých lidí, rozpozná nekorektní argumentaci a manipulativní strategie v mezilidské komunikaci

- zhodnotí význam vědeckého poznání, techniky a nových technologií pro praktický život i možná rizika jejich zneužití 
- posuzuje lidské jednání z hlediska etických norem a svědomí jednotlivce, objasní dějinnou proměnlivost základních etických pojmů a norem

- rozlišuje významné náboženské systémy, identifikuje projevy náboženské a jiné nesnášenlivosti a rozezná projevy sektářského myšlení

\section{Učivo}

- podstata filozofie - základní filozofické otázky, vztah filozofie k mýtu, náboženství, vědě a umění

- filozofie v dějinách - klíčové etapy a směry filozofického myšlení

- víra v lidském životě - podoby víry, znaky náboženské víry; náboženské systémy, církve; sekty ${ }^{1}$

Předpokládaná výchozí úroveň informovanosti standardního studenta na začátku září posledního ročníku? Z dějepisu si přináší souhrnný přehled o etapách civilizačního vývoje, především evropského, v hrubých rysech by dal dohromady obecné charakteristiky např. antiky, renesance či osvícenství. $\mathrm{V}$ této souvislosti zaslechl jména několika filozofických myslitelů. O moderních filozofických vlivech na literaturu se něco dozví teprve během školního roku. Je-li vychováván v prostředí víry, orientuje se v (jednom) náboženství.

Jeho názor na filozofii? Složitá, zčásti tajemná disciplína, historicky zřejmě zdroj moudrých myšlenek, ale asi nic pro mě. Religionistika? Neníli zde onen rodinný dotek víry, tak asi nic, nebo povrchní střípky, například o popularizovaném buddhismu.

Jak si s těmito východisky, tematickou rozlehlostí a realitou času poradí učitelé? Ze zkušenosti oborového didaktika na Katedře filozofie vím, že posluchači učitelského směru přicházejí po absolvování výukové praxe se zjištěním, že se na gymnáziu v hodinách ZSV učí chronologické dějiny filozofie. Cvičná praxe posluchačů probíhá na podzim a v zimě a podle záznamů o absolvovaných hodinách se $\mathrm{v}$ té době pohybují v antice nebo ve středověku, přičemž jsou témata probírána dosti zevrubně. Nevím, zda se učitelé stihnou dostat na jaře k filozofickým směrům moderním, ba současným.

Nejsem však pouze oborovým didaktikem na částečný úvazek na katedře. Svou podstatou a 90 procenty veškeré své pedagogické činnosti jsem léta letoucí gymnaziálním učitelem ZSV, a tudíž i filozofie. Dlouho jsem s obtížemi hledal způsob, jak harmonizovat skutečnosti, jež uvádím na začátku tohoto zamyšlení, s výsledky, o něž usiluji a které mohu reálně očekávat. Jsem také češtinář a kdysi se mi dostala do ruky útlá brožurka z konce 20. let minulého

www.nuv.cz/file/159, s. 142. 
století, jejímž autorem je Arne Novák. Fascinoval mě její název: České písemnictví z ptačí perspektivy. To je ono! Žáci, s nimiž na gymnáziu absolvuji pout filozofií, se budou vznášet nad krajinou evropského myšlení, budou vidět hlavní proudy (ř ek nebo událostí) a jejich větvení, sítě cest mezi nimi a velkými postavami, kde spolu ladí a kde se názorově střetávají - a to všechno alespoň v přibližných časových souvislostech s tím, co žáci znají z dějepisu, literatury či dějin umění.

Pro výuku všech dílčích disciplín předmětu ZSV jsem si vymyslel podobenství o muzeu. Například - at nemluvím pořád jen o filozofii - máme začít probírat sociologii. Předpokládejme, že je to - velice pravděpodobně - pro žáky celkem bezobsažné slovo. „Jdeme“ tedy společně do zvláštního muzea, které se jmenuje Sociologie. V pokladně každému studentovi dají soupis všech exponátů, které jsou uvnitř a které v souhrnu představují „vše o sociologii“. Průvodcem jsem žákům já. Nepodělím čas, který máme pro návštěvu muzea k dispozici, počtem exponátů, abychom se u každého mohli zastavit na stejně dlouhou (= krátkou) dobu. Mám „prohlídku“ promyšlenu tak, že u některých vitrín se zdržíme déle, některé naopak téměř mineme, pouze upozorním na jejich souvislost s dalšími exponáty. V některých místnostech muzea setrváme dlouho, o obsahu jiných se svým žákům pouze zmíním. Když pak vycházíme z muzea - mají žáci v rukou celkem podrobný soupis exponátů a v hlavě relativně ucelenou představu o tom, co to asi ta sociologie je.

Kdysi jsem podnikal podobnou návštěvu muzea, které nese název Filozofie, jednou. Dlouho jsem totiž učil filozofii oním chronologickým způsobem. Samozrejmě, že jsem to dělal pokud možno zajímavě, aby to především bavilo mě (protože pak je naděje, že to bude bavit i studenty - tedy alespoň jejich větší část). Postupně však ve mně víc a víc sílil dojem, že to není úplně ono: filozofické proudy proudí, filozofové přicházejí jako apoštolové na orloji, sdělí svoje moudra (ontologická, epistemologická, případně i něco o společnosti či etice, ba i nějaký svůj text zadeklamují) - a mizí v šeru času, už se s nimi nikdy nesetkáme. Před nějakými dvaceti lety jsem se proto rozhodl, že do muzea Filozofie „půjdeme“ třikrát. Vybaveni poměrně podrobným rozpisem témat podle desetinného systému, rozdělených do tří kapitol: Jaký svět je, Zda a jak ho můžeme poznat a Jak se to vztahuje k hodnotám, k člověku a etice jeho jednání. U některých exponátů (osobností) se tedy zastavíme při každé z našich tří návštěv, jiné při některé mineme, a věnujeme se jim př́šstě.

(A co ty základy religionistiky? Když probíráme filozofický úvod - srovnání s vědou, uměním, mýtem - dojdeme i ke vztahu mezi filozofií a náboženstvím. A to je správný okamžik pro trochu obsáhlejší odbočku: v muzeu 
navštívíme sín s názvem Religionistika, zdržíme se v ní potřebnou dobu a pak se zase vrátíme do hlavní expozice a pokračujeme kolem ostatních vitrín.)

Závěr? Zkuste si to.

\section{PhDr. Tomáš Měštánek}

Katedra filozofie, Filozofická fakulta, Masarykova univerzita

Arna Nováka 1, 60200 Brno, Česká republika

33870@mail.muni.cz 